1975b. Some new or otherwise interesting members of the Calyptraeidae (Mollusca: Gastropoda). Tulane Studies in Geology and Paleontology, 11:163-172.

VOKES, H. E. 1957. Miocene fossils of Maryland. Department of Geology, Mines and Water Resources, Bulletin 20, 85 p.

VyaLOV, O. S. 1936. Sur la classification des huîtres. Comptes rendus (Doklady) de l'Académie des Sciences de l'URSS, new series, 4:1720.

WARD, L. W. 1984. Stratigraphy of outcropping Tertiary beds along the Pamunkey River-central Virginia Coastal Plain, p. 11-77. In L. W. Ward and K. Krafft (eds.), Stratigraphy and Paleontology of the Outcropping Tertiary Beds in the Pamunkey River Region, Central Virginia Coastal Plain. Guidebook for the 1984 Field Trip, Atlantic Coastal Plain Geological Association.

- AND B. W. BLACKWELDER. 1980. Stratigraphy of Eocene, Oligocene, and lower Miocene formations-Coastal Plain of the Carolinas, p. 190-208. In R. W. Frey (ed.), Excursions in Southeastern Geology, Volume I. American Geological Institute.

, G. S. GOHN, AND R. Z. POORE. 1979. Stratigraphic revision of Eocene, Oligocene and lower Miocene Formations of South Carolina. Geologic Notes, 23:2-32.

-, D. R. LAWRENCE, AND B. W. BlackWELDER. 1978. Stratigraphic revision of the Middle Eocene, Oligocene, and Lower MioceneAtlantic Coastal Plain of North Carolina. U.S. Geological Survey Bulletin 1457-F, $23 \mathrm{p}$.

WENZ, W. 1938-1944. Gastropoda. Volume 6, 7 parts. In O. H. Schindewolf (ed.), Handbuch der Paläozoologie. Gebrüder Borntraeger, Berlin, 1639 p.

White, C. A. 1887. Contribuições á paleontologia do Brazil. Archivos do Museu Nacional do Rio de Janeiro, 7:1-273.

Wilson D. 1987a. A new pycnodont oyster from the Pungo River Formation, and an annotated list of the Cenozoic pycnodonts of the Atlantic and Gulf Coastal Plain, p. 13-20. In C. E. Ray (ed.), Geology and Paleontology of the Lee Creek Mine, North Carolina II. Smithsonian Contributions to Paleobiology 61 .

- 1987b. Species of Ecphora, including the subgenus Stenomphalus, in the Pungo River Formation, p. 21-29. In C. E. Ray (ed.), Geology and Paleontology of the Lee Creek Mine, North Carolina II. Smithsonian Contributions to Paleobiology 61.
Wood, W. 1828. Index Testaceologicus; or a Catalogue of Shells, British and Foreign, Arranged According to the Linnean System, etc. Second [i.e., third] Edition. 212 p. Also: Supplement, etc. (references from Lamarck's "Animaux sans Vertebres, " adapted to the figures in the ... "Index," etc.). 59 p. [not seen].

WoODRING, W. P. 1928. Miocene mollusks from Bowden, Jamaica; Part II, gastropods and discussion of results. Contributions to the Geology and Paleontology of the West Indies, Carnegie Institution of Washington Publication 385, 564 p.

- 1959. Geology and paleontology of Canal Zone and adjoining parts of Panama. Description of Tertiary mollusks (Gastropods: Vermetidae to Thaididae). U.S. Geological Survey Professional Paper 306-B:147-239.

- 1973. Geology and paleontology of Canal Zone and adjoining parts of Panama. Description of Tertiary mollusks (Additions to gastropods, scaphopods, pelecypods: Nuculidae to Malleidae). U.S. Geological Survey Professional Paper 306-E:453-539.

WOODWARD, S. P. 1851. A Manual of the Mollusca: or a Rudimentary Treatise of Recent and Fossil Shells, Part 1. London, $158 \mathrm{p}$.

WrigleY, A. 1932. English Eocene species of Sassia, with a note on the morphology of the Cymatiidae and the Bursidae. Proceedings, Malacological Society of London, 20:127-140.

ZARRA, L. 1983. Biostratigraphy of planktonic foraminifera from Oligocene and lowermost Miocene rocks of the North Carolina Coastal Plain. Geological Society of America, Abstracts with Programs, 15: 726.

- 1989. Sequence stratigraphy and foraminiferal biostratigraphy for selected wells in the Albemarle Embayment, North Carolina. North Carolina Geological Survey Open-file Report 89-5, 48 p.

ZuLlo, V. A. 1984. New genera and species of balanoid barnacles from the Oligocene and Miocene of North Carolina. Journal of $\mathrm{Pa}$ leontology, 58: 1312-1338.

-, AND G. R. BAUM. 1979. Paleogene barnacles from the Coastal Plain of North Carolina (Cirripedia, Thoracica). Southeastern Geology, 20:229-246.

ACCEPTED 13 JULY 1990

\title{
ANNOUNCEMENT
}

\section{NOMINATIONS FOR THE PALEONTOLOGICAL SOCIETY MEDAL AWARD AND THE CHARLES SCHUCHERT AWARD}

Nominations are now being accepted for candidates for the Society's Medal and Schuchert Award. Send nominations to John Pojeta, Jr., Chairman, Medal and Schuchert Award Committees, Paleontology and Stratigraphy Branch, U.S. Geological Survey, National Center-MS 982, Reston, Virginia 22092, U.S.A.; telephone 703-648-5288. Criteria for the awards are listed in the Journal, 1987, p. 862, 863, By-Laws Chapters 12, 13.

In an effort to make sure that the Committees have information by which they can compare apples to apples between the various candidates' credentials, at a minimum it is asked that the dossier for each candidate contains the following information:

1. Letter of nomination

2. Letters of support for the candidate

3. A CV or equivalent

4. Information about the candidate's research accomplishments and their impact

5. Professional outreach

6. Contributions other than research

7. Special honors received

8. Anything else that is deemed to be appropriate, e.g., newspaper clippings, etc.

Have the completed dossiers to the Committees' Chairman by March 15, 1991. 